\title{
КОМУНІКАТИВНІ ДЕВІАЦІЇ В ПРОЦЕСІ ПЕРЕКЛАДУ ПОЛЬСЬКОГО ПРАВОВОГО ТЕКСТУ
}

\author{
ОЛЕНА КОВАЛЕВСЬКА \\ Університет імені Адама Міцкевича, Познань - Польща \\ gomeniuk.olena@gmail.com; ORCID: 0000-0003-1241-449X \\ ОКСАНА ДУФЕНЮК \\ Львівський державний університет внутрішніх справ, Львів - Україна \\ oxpostfb@ukr.net; ORCID: 0000-0001-6529-4036

\section{BŁĘDY KOMUNIKACYJNE W TŁUMACZENIU POLSKIEGO TEKSTU PRAWNEGO} \\ OLENA KOWALEWSKA \\ Uniwersytet im. Adama Mickiewicza, Poznań — Polska \\ OKSANA DUFENIUK \\ Lwowski Państwowy Uniwersytet Spraw Wewnętrznych, Lwów — Ukraina
}

STRESZCZENIE. Artykuł został poświęcony kwestii błędów komunikacyjnych w procesie tłumaczenia polskiego tekstu prawnego na język ukraiński. Aktualność tematu badawczego wynika z konieczności zapewnienia ukraińskim prawnikom szerszego dostępu do polskojęzycznych aktów prawnych. Wzmożone zainteresowanie jest rezultatem sprawności wprowadzania przez Polskę europejskich praktyk $\mathrm{w}$ interpretacji prawa. $\mathrm{W}$ artykule został przedstawiony schemat komparatystycznej analizy polskich tekstów prawnych i prawniczych, scharakteryzowano grupy terminów prawnych pod względem trudności ich tłumaczenia na język ukraiński oraz określono najczęstsze przyczyny powstawania błędów komunikacyjnych. Tłumaczenie polskiego tekstu prawnego wymaga od thumacza nie tylko doskonałej znajomości języka polskiego i ukraińskiego, ale także obowiązującego ustawodawstwa obu państw. Wspólna praca językoznawców, tłumaczy i prawników nad tworzeniem dwujęzycznych słowników terminologicznych pozwoli uniknąć błędów, które można zaobserwować w tłumaczeniach polskich tekstów prawnych na język ukraiński.

Słowa kluczowe: polski tekst prawny, błędy komunikacyjne, tłumaczenie terminów prawnych na język ukraiński, dwujęzyczne słowniki terminologiczne 


\title{
COMMUNICATIVE DEVIATIONS IN TRASLATING POLISH LEGAL TEXT
}

\author{
OLENA KOVALEVSKA \\ Adam Mickiewicz University, Poznan — Poland \\ OKSANA DUFENIUK \\ Lviv State University of Internal Affairs, Lviv — Ukraine
}

\begin{abstract}
The article elucidates problems of translating Polish legal texts into Ukrainian. The topicality of the study consists in the necessity to provide Ukrainian lawyers with an open access to Polish legal acts. The importance of such an enterprise is enhanced by the fact of introducing European criteria of interpreting laws into the Polish legal practice. The author elaborates a scheme of comparative analysis of Polish legal texts, subdivides Polish legal terms into groups depending on difficulties of their translating into Ukrainian, describes common translation deviations. Adequate translation of Polish legal texts requires not only fluency in Polish and Ukrainian, but also some specialized knowledge of laws of both countries. The joint work of linguists, lawyers and translators will help to avoid typical mistakes found in translations of legal acts from Polish into Ukrainian.
\end{abstract}

Key words: Polish legal text, communicative deviations, translating of legal terms into Ukrainian, bilingual terminological dictionaries

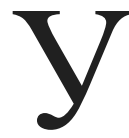

контексті провадження в Україні реформ, в основі яких лежить прагнення наблизити систему права до стандартів європейської правової культури, особливої важливості набуває тематика порівняльно-правових досліджень. Польща видається одним із кращих прикладів успішного провадження проєвропейських реформ, що, безумовно, активізує проведення комплексних інтердисциплінарних досліджень. Передусім це посилює зростання важливості перекладознавства.

Проблеми перекладу правових текстів і юридичної термінології стали предметом розвідок польських й українських науковців, зокрема Л. Андрієнко, М. Жевуської, А. Йопек-Босяцької, Д. Кешковської, К. Літвін, Й. Познанського, Г. Сорокіної, Л. Черноватого, С. Хипса, В. Шабуніної, І. Шумило та ін. Зауважмо, що значну кількість становлять праці, присвячені питанням перекладу англійських правових текстів.

Незважаючи на сусідство України й Польщі, а також взаємне співробітництво в галузі правових відносин, проблематиці польськоукраїнського юридичного перекладу присвячено небагато праць. Сьогодні єдиним словником у досліджуваній сфері є Украӥнсько-польський, польськоукраӥнський термінологічний словник: право, фінанси, економіка, торгівля, укладений І. Яценком [Яценко 2004]. Видання охоплює понад 45 тис. термінів 
сучасної юридичної галузі та діловодства. Заслуговує на увагу також укладений І. Кононенко, І. Митнік та Е. Васяк Stownik tematyczny polsko-ukraiński [Kononenko 2010], у якому один iз 30 тематичних блоків присвячений праву та протидії злочинності. Однак з огляду на динамічність розвитку правової та юридичної лексики цього не достатньо, щоб задовольнити потреби дослідників та перекладачів.

Актуальність тематики коректного перекладу польського правового тексту також зумовлена необхідністю надання українським правникам більш широкого доступу до польськомовних нормативно-правових актів. Це дасть змогу українським науковцям та практикам реалізувати гносеологічні можливості в таких аспектах:

- сутнісному (можливість ознайомитися 3 інтерпретуванням суб’єктом правотворчої діяльності правових понять, норм та інститутів, їхньою структурою, механізмом, формами, гарантіями, типологією тощо);

-методологічному (можливість пізнати фундаментальні засади функціювання правових понять, норм та інститутів);

- аналітичному (можливість аналізування, поглибленого дослідження, оцінення окремих правових понять, норм та інститутів; можливість виявлення позитивного досвіду правового регулювання правових відносин, розв'язання практичних проблем правозастосовної практики);

-компаративному (можливість порівняння норм польського й українського права; можливість формулювання висновків щодо відповідності нормативно-правового регулювання європейським стандартам).

Схема компаративного аналізу польського тексту нормативно-правових актів (тексту законів, підзаконних правових актів) передбачає проходження таких етапів:

1) виокремлення фрагменту для перекладання (первинний зміст);

2) перекладання тексту (вторинний зміст);

3) зіставлення й оцінювання вторинного змісту чужомовного тексту й первинного змісту аналогічного фрагменту тексту українського законодавства;

4) формулювання окремих висновків щодо спільних і відмінних змістовних пунктів;

5) формулювання загальних висновків і пропозицій щодо ефективності правового регулювання, необхідності впровадження нових правових інститутів тощо.

Якщо перший етап не викликає жодних труднощів у потенційного дослідника, то на другому етапі виявляється проблема, що може суттєво вплинути на перебіг усіх наступних етапів роботи. Ідеться про тонкощі використання категорійно-поняттєвого апарату в ході порівняльно-аналітичного дослідження чужомовного тексту законодавства. Очевидно, що переклад правового тексту з однієї мови на іншу може дещо трансформувати початковий зміст поняття 
й у процесі такого трансформування можлива деяка втрата або змінення первинного смислового навантаження, оскільки йдеться про спеціальні поняття, сформовані в певному специфічному соціокультурному середовищі під впливом історичних і навіть ментальних чинників.

Як наслідок, можуть виникати комунікативні девіації в сенсі, описаному А. Кравчук у науковій праці, присвяченій дослідженню комунікативних невдач під час вербального спілкування мовців. Зазначена дослідниця розуміє комунікативні невдачі як такі ситуації вербальної комунікації, що становлять різного ступеня непорозуміння між адресатом й адресантом, що $\epsilon$ наслідком не мовних помилок в опозиції до нормативного, “правильного" вживання одиниць мовної системи, не будь-якого відхилення від мовної норми, а тільки таких порушень, що спричиняють різного ступеня комунікативний дискомфорт - від повного непорозуміння (“провалу”), недосягнення адресантом іллокутивної мети або досягнення ії з певними труднощами [Кравчук 2012: 113-114]. При цьому А. Кравчук наводить понад 15 різних відповідників цього терміна в польській мові: fiasko konwersacyjne, kryzys interakcyjny, kryzys komunikacyjny, zaburzenie interakcji, nieporozumienie interakcji, nieporozumienie $w$ konwersacji, zaburzenie procesu komunikowania się, załamanie procesu komunikacji, kryzys konwersacyjny, zakłócenie konwersacyjne, zaktócenie procesu komunikacji, blokada komunikacji, porażka komunikacyjna, zaktócenie (w) komunikacji, usterki / pomytki / błędy komunikowania, nieporozumienia / utrudnienia / niedoskonatości / bariery $w$ komunikowaniu [Кравчук 2012: 113].

Розгляньмо більш детально комунікативні девіації, що виявляються під час перекладання польського правового тексту українською мовою на прикладі кримінального процесуального законодавства. Передусім звернімо увагу на дві особливості, зумовлені специфікою об'єкта перекладання. По-перше, переклад регламентації кримінального провадження в кожній країні, як i норм правового регулювання будь-якої сфери правових відносин, має суттєву відмінність від звичайного (побутового) вербального спілкування чи перекладання художньої або публіцистичної літератури. Норма права потребує підвищеної концентрації зусиль і мовних засобів, щоб максимально точно передати зміст у рідному контексті й щоб адресат (дослідник-перекладач) інтерпретував його відповідно до інтенції адресанта (нормотворця), адже інколи навіть використання сполучників $m a$ / або повністю змінює суть норми й можливості її застосування на практиці. По-друге, обов'язковою умовою роботи з текстом польського законодавства $\epsilon$ необхідність широкого використання правових термінів та їхніх понять, однак цей процес може супроводжуватися проблемами чотирьох рівнів:

1) у польському законодавстві не всі вживані терміни та їхні поняття мають законодавче визначення; 
2) не всі правові терміни і їхні поняття польського законодавства мають свій відповідник в українському;

3) в українському законодавстві існують терміни та їхні поняття, що не мають відповідників у польському;

4) відсутнє однозначне розуміння поняття й визначення термінів і в польській, і в українській мовах.

У різних правових системах терміни зазвичай концептуально несумісні, оскільки набувають значень, що сформувалися під впливом відмінних культурних реалій. Про це явище пише польський мовознавець Є. Пенькос, порівн.: „Семантична невизначеність, характерна для юридично-правової лексики, виникає тому, що у світі немає двох однакових правових систем, навіть у межах однієї політичної чи ідеологічної спільноти” [Pieńkos 1999: 158] (переклад автор. - О. К. й О. Д.). Як стверджує Д. Кешковська: „Лише сам факт існування відмінностей між змістом понять різних правових систем дасть нам змогу у процесі перекладання термінів, що до них належать, завжди усвідомлювати існування цих відмінностей і бути готовими їх урахувати” [Kierzkowska 2002: 23] (переклад автор. - О. К. й О.Д.).

Системний аналіз термінів та їхніх понять, що вживаються в кримінальному процесуальному кодексі Республіки Польща (далі - КПК Польщі) [Ustawa 1997], залежно від ступеня складності їхнього перекладання дає право виокремити дві категорії:

1) проста група - репрезентує терміни та їхні поняття, що дають змогу реалізувати найвищий ступінь збігання перлокуції з іллокуцією, оскільки мають відповідники з аналогічним змістом у кримінальному процесуальному кодексі України (далі - КПК України) [Кримінальний процесуальний кодекс 2012]. До цієї групи можемо зарахувати такі терміни: postepowanie karne, sprawca przestęstwa, prawo do obrony, popetnione przestępstwo, pozbawienie wolności, polecenia sądu, prokurator, zażalenie, sprawozdanie, apelacja, kasacja, biegty, wniosek strony, pokrzywdzony, szkoda, wszczęcie postępowania, akt oskarżenia, kwalifikacja prawna, niebezpieczeństwo, tymczasowe aresztowanie, dowód та ін.;

2) складна група - містить терміни та їхні поняття, що дають змогу реалізувати менший ступінь збігання перлокуції з іллокуцією, потребують застосування нових конструкцій передавання інтенсіоналу (ядра) поняття й додаткових мовних засобів. У цій групі залежно від причини, що зумовлює складність, можна виокремити три підгрупи:

a) терміни та їхні поняття можна перекласти, але передавання змісту може бути неточним і потребувати звернення до інших нормативних актів з метою формування повного та адекватного розуміння того, що законотворець передбачав, використовуючи такі терміни й терміносполучення, напр.: organy prowadzace postępowanie karne, organ powolany do ścigania przestęstw, organ powołanydonadzorunadjednostkąorganizacyjna, postępowanie przygotowawcze, 
instytucja uprawniona do ścigania przestęstw, czyn ścigany z urzędu, pierwsza rozprawa główna, kara prawomocnie orzeczona, postepowanie mediacyjne, prawomocny wyrok, petnomocnik та ін.;

б) терміни та їхні поняття оцінної категорії, що можуть бути перекладені буквально, але їхній зміст у певному соціокультурному середовищі може мати відповідні відмінності, і чіткі визначення цих понять відсутні і в українському, і в польському законодавствах, напр.: zasady wspólżycia społecznego, zasady prawidłowego rozumowania, wskazanie wiedzy, doświadczenie życiowe, ścisty związek z czynem, w miare potrzeby, społeczna szkodliwość znikoma, dtugotrwała przeszkoda, szczególna zawiłość sprawy, niezwłocznie, bezskutecznie та ін.;

в) терміни та їхні поняття, що позначають відсутні в українському законодавстві правові інститути, дії, рішення чи факти: referendarz sądowy, asesor prokuratorski, oskarżyciel posiłkowy, wniosek o sprostowanie protokołu, wywiad środowiskowy, list gończy, list żelazny тощо.

3 позиції перекладача значна частина термінів і правової терміносистеми КПК Польщі належить до другої групи. Відтак виникає небезпека імплементації в практичну площину неправильно трактованих правових дефініцій. Комунікативна девіація при цьому виявляється в таких формах: неправильне розуміння правового поняття; неправильне застосування правничої термінології; некоректне апелювання до норм статей, параграфів; неврахування деталей норми права (при відсильній і банкетній формі), викладених в інших нормативно-правових актах; трансформація розуміння правового поняття (простої групи) з української мови в перекладений фрагмент, хоча зміст цього поняття в польському кримінальному процесі має юридично інше значення. У процесі роботи 3 польським правовим текстом такі проблеми можуть виникати й унаслідок надмірно точного, дослівного перекладання й через надто вільне, абстраговане від деталей перекладання. Правова норма повинна бути чіткою, логічною, максимально точною, але все-таки домінувати повинен не стільки формальний аспект буквального перекладання, скільки розуміння сутності поняття, функціювання правового інституту (змістовний аспект). Орієнтування під час перекладання на зміст означає необхідність правильного інтерпретування значення спеціальних одиниць у контексті [Техніка перекладу 2019]. Зокрема, поняття "obrońca z urzędu” може бути дослівно інтерпретовано як 'захисник від установи' або 'захисник від управління', 'захисник від уряду', що відповідатиме конструкту 'захисник за призначенням’ в українському процесуальному праві. Тож більш доречним буде підхід використання поняття “захисник за призначенням”, оскільки це дає змогу в подальшому порівняльному дослідженні оперувати цим поняттям, не 3'ясовуючи, чи є такий інститут в КПК України. Актуальним є питання про особливості (подібності, відмінності) функціювання цього інституту в КПК Польщі порівняно з КПК України. 
Отже, перекладання польського правого тексту вимагає від дослідника-перекладача не лише бездоганного володіння польською та українською мовами, а й обізнаності в чинному законодавстві обох країн. Спорідненість мов часто ускладнює переклад таких текстів, створюючи численні “мовні пастки”. Проблеми перекладання юридичної термінології повинні бути в центрі уваги не лише мовознавців і перекладачів, але й правників. Спільні напрацювання зі створення двомовних термінологічних словників дадуть змогу уникнути комунікативних девіацій, що, на жаль, спостерігаються в перекладах польських правових текстів українською мовою.

\section{Список використаної літератури}

Кравчук А., Граматика і успішність комунікаиії (дещо з польсько-украӥнських граматичних контрастів), [в:] „Проблеми слов'янознавства”, 2012, вип. 61, с. 111-128.

Техніка перекладу, [в:] Електронний ресурс: http://ukrarticles.pp.ua/nauka/10923-texnikaperevoda.html (03.01.2019).

Kierzkowska D., Ttumaczenie prawnicze, Warszawa: Wydawnictwo TEPIS, 2002.

Pieńkos J., Podstawy juryslingwistyki. Język w prawie — prawo w języku, Warszawa: Oficyna Prawnicza Muza S. A., 1999.

Ustawa z dnia 6 czerwca 1997. Kodeks postepowania karnego (Dz. U. Nr 89, poz. 555 z pón. zm.), [w:] Źródło elektroniczne: http://prawo.sejm.gov.pl/isap.nsf/DocDetails. xsp?id=WDU19970890555 (04.01.2019).

\section{Spysok vykorystanoi literatury [References]}

KravchukA.,Hramatyka iuspishnist komunikatsii(deshcho zpolsko-ukrainskykhhramatychnykh kontrastiv) [Grammar and Effective Communication (Some Polish-Ukrainian Grammar Contrasts], [v:] „Problemy slovianoznavstva”, 2012, vyp. 61, s. 111-128.

Tekhnika perekladu [Technique of Translation], [v:] Elektronnyi resurs: http://ukrarticles.pp.ua/ nauka/10923-texnika-perevoda.html (03.01.2019).

Kierzkowska D., Ttumaczenie prawnicze [Law Translation], Warszawa: Wydawnictwo TEPIS, 2002 .

Pieńkos J., Podstawy juryslingwistyki. Język $w$ prawie - prawo $w$ języku [Basics of Juryslinguistics - Language in Law, Law in Language], Warszawa: Oficyna Prawnicza Muza S. A., 1999.

Ustawa z dnia 6 czerwca 1997 r. Kodeks postępowania karnego (Dz. U. Nr 89, poz. 555 $\mathrm{z}$ pón. zm.) [The Act from the $6^{\text {th }}$ of June 1997. Code of Criminal Procedure], [w:] Źródło 
elektroniczne: http://prawo.sejm.gov.pl/isap.nsf/DocDetails.xsp?id=WDU19970890555

(04.01.2019).

\section{Список використаних джерел}

Кримінальний процесуальний кодекс Украйни від 13.04.2012 р., [в:] Електронний ресурс: https://zakon.rada.gov.ua/laws/show/4651-17 (04.01.2019).

Яценко І., Украӥнсько-польський, польсько-український термінологічний словник: право, фінанси, економіка, торгівля, Київ: Школа, 2004.

Kononenko I., Mytnik I., Wasiak E., Słownik tematyczny polsko-ukraiński, Warszawa: Wydawnictwo Naukowe PWN SA, 2010.

\section{Spysok vykorystanykh dzherel [References]}

Kryminalnyi protsesualnyi kodeks Ukrainy [Criminal Procedural Code of Ukraine] vid 13.04.2012 r., [v:] Elektronnyi resurs: https://zakon.rada.gov.ua/laws/show/4651-17 (04.01.2019).

Yatsenko I., Ukrainsko-polskyi, polsko-ukrainskyi terminolohichnyi slovnyk: pravo, finansy, ekonomika, torhivlia [Ukrainian-Polish, Polish-Ukrainian Terminology Dictionary: Law, Finance, Economics, Trade], Kyiv: Shkola, 2004.

Kononenko I., Mytnik I., Wasiak E., Słownik tematyczny polsko-ukraiński [Polish-Ukrainian Thematic Dictionary], Warszawa: Wydawnictwo Naukowe PWN SA, 2010. 